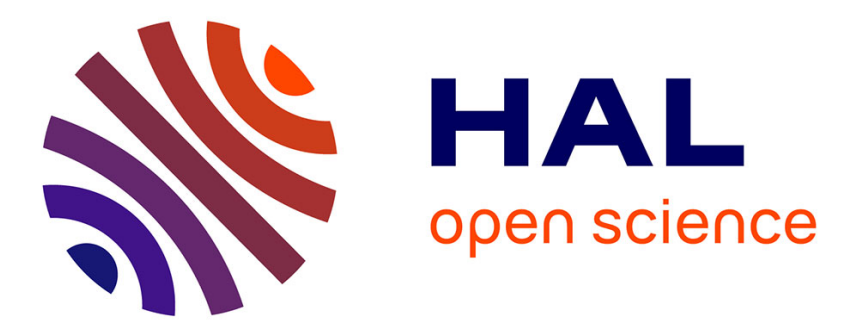

\title{
Silicone rheological behavior modification for 3D printing: Evaluation of yield stress impact on printed object properties
}

\author{
Edwin-Joffrey Courtial, Clément Perrinet, Arthur Colly, David Mariot, \\ Jean-Marc Frances, René Fulchiron, Christophe Marquette
}

\section{To cite this version:}

Edwin-Joffrey Courtial, Clément Perrinet, Arthur Colly, David Mariot, Jean-Marc Frances, et al.. Silicone rheological behavior modification for 3D printing: Evaluation of yield stress impact on printed object properties. Additive Manufacturing, 2019, 28, pp.50-57. 10.1016/j.addma.2019.04.006 . hal02338110

\section{HAL Id: hal-02338110 \\ https://hal.science/hal-02338110}

Submitted on 21 Dec 2021

HAL is a multi-disciplinary open access archive for the deposit and dissemination of scientific research documents, whether they are published or not. The documents may come from teaching and research institutions in France or abroad, or from public or private research centers.
L'archive ouverte pluridisciplinaire HAL, est destinée au dépôt et à la diffusion de documents scientifiques de niveau recherche, publiés ou non, émanant des établissements d'enseignement et de recherche français ou étrangers, des laboratoires publics ou privés.

\section{()ㅜ(1)}

Distributed under a Creative Commons Attribution - NonCommerciall 4.0 International 


\title{
Wind Speed Data Analysis Using Weibull and Rayleigh Distribution Functions, Case Study: Five Cities Northern Morocco
}

\author{
Hicham Bidaoui $^{\mathrm{a}, \mathrm{b}, *}$, Ikram El Abbassi ${ }^{\mathrm{b}}$, Abdelmajid El Bouardi ${ }^{\mathrm{a}}$, \\ Abdelmoumen Darcherif ${ }^{b}$ \\ ${ }^{a}$ Department of Physics, Faculty of sciences, Abdelmalek Essaadi University, Tetouan,Morocco. \\ ${ }^{b}$ ECAM-EPMI, Graduate School of Engineering, Cergy-Pontoise, 95052, France.
}

\begin{abstract}
The aim of the present paper is to evaluate and discuss the Energy wind potential of five major cities in Northern Morocco. The theoretical analysis is based on stochastic models of Weibull and Rayleigh using Probability Density Function approach. Various statistical indicators such as the determination coefficient $\left(\mathrm{R}^{2}\right)$, Chi square error $\left(\chi^{2}\right)$, root mean square error (RMSE) and mean bias error (MBE) are considered. Then, a numerical simulation of the potential electrical power is carried out using the Enercon E103/2350 wind turbine model. The results show that Weibull is more accurate than Rayleigh, especially for Tetuan and AlHoceima cities. Concerning electrical energy production, only the sites of Tetouan and Tangier gave interesting values.
\end{abstract}

(C) 2018 The Authors. Published by Elsevier Ltd.

This is an open access article under the CC BY-NC-ND license (https://creativecommons.org/licenses/by-nc-nd/4.0/)

Selection and peer-review under responsibility of the 12th International Conference Interdisciplinarity in Engineering.

Keywords: Weibull distribution; Rayleigh distribution; Wind speed; Probability density function; Wind rose.

\section{Introduction}

In recent years, world's energy consumption has been increasing due to economic and social development in both modern and emergent countries. The fast growing energy demand is particularly visible in Africa. While the world energy production reached 13790 Mtoe in 2015, the African continent saw its consumption rose to $8 \%$ versus $0.6 \%$

\footnotetext{
* Corresponding author.

E-mail address: bidaouihicham@gmail.com
}

2351-9789 (C) 2018 The Authors. Published by Elsevier Ltd.

This is an open access article under the CC BY-NC-ND license (https://creativecommons.org/licenses/by-nc-nd/4.0/)

Selection and peer-review under responsibility of the 12th International Conference Interdisciplinarity in Engineering. 
in 2014. While, energy demand rose only by $0.5 \%$ in non-OECD (Organization for Economic Co-operation and Development) countries. and decreased by $0.3 \%$ in OECD [1].

Wind is one of the most important renewable energy sources. Indeed, the wind energy is well developed, controlled and accessible. However, in order to increase wind farm's electrical production performance in a given location, a deep analysis of wind characteristics is required [2], [3]. Recently, researchers have shown increased interest in wind energy potential in several regions of the world using miscellaneous probability density functions (PDF).

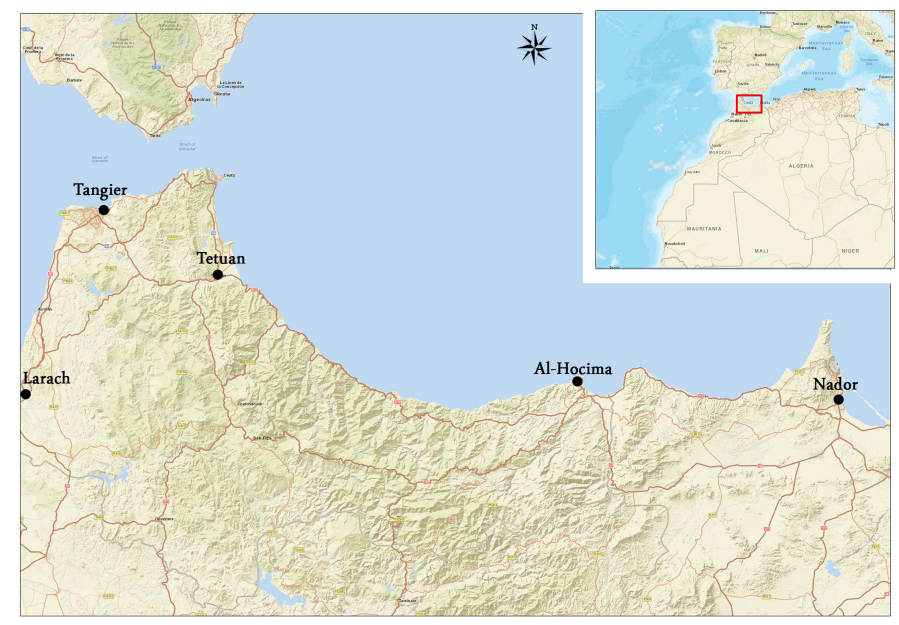

Fig. 1. Map of the locations of measurement stations.

In this paper, Weibull and Rayleigh PDFs are used to describe wind speed probability in five cities in Northern Morocco (Fig. 1); they are the most widely used in literature, as well as their good accuracy in describing and predicting wind speed distribution in many regions of the world PDF.

The objective here is threefold i) to find the theoretical model closest to the experimental reality for extrapolation to other geographical areas in the southern Mediterranean, ii) to determine among the five cities those with the best potential Wind turbine, iii) and to use the models in the sizing of wind farms according to the geographical specificities of the site.

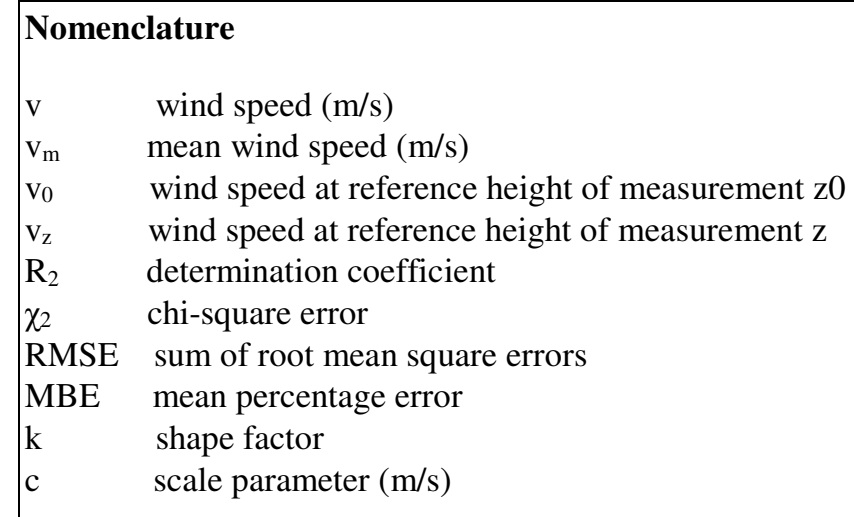




\section{Materials and methods}

\subsection{Dual-fed antenna design Weibull probability and cumulative distribution function}

It's the widely two parameters distribution function used in literature for describing wind speed data in many regions. The variations in wind velocity are characterized by two functions: "The probability density function" and "The cumulative distribution function". The first function indicates the percent of time for which the wind flows with a specific wind speed. It's mathematically expressed as follow [4], [5]:

$$
f_{w}(v)=\left(\frac{k}{c}\right)\left(\frac{v}{c}\right)^{k-1} \cdot \exp \left[-\left(\frac{v}{c}\right)^{k}\right]
$$

The cumulative distribution function gives the percent of time that the wind speed is less than or equal the wind speed $v_{0}$, it's expressed by the integral of the probability density function.

$$
F\left(v \leq v_{0}\right)=1-\exp \left[-\left(\frac{v}{c}\right)^{k}\right]
$$

\subsection{Rayleigh probability and cumulative distribution function}

The Rayleigh distribution, which is a special case of Weibull distribution with a fixed shape parameter value $k=2$, is defined by [6], [7]:

$$
f_{r}(v)=\frac{\pi v}{2 v_{m}^{2}} \exp \left[-\frac{\pi}{4}\left(\frac{v}{v_{m}}\right)^{2}\right]
$$

The Rayleigh cumulative distribution function is given by:

$$
F\left(v \leq v_{0}\right)=1-\exp \left[-\frac{\pi}{4}\left(\frac{v}{v_{m}}\right)^{2}\right]
$$

\subsection{Extrapolation of wind speed at different hub height}

The observed data used in this study were measured at $10 \mathrm{~m}$ height. While most of commercial wind turbine have different hub height. The Hellman's exponential law was used to extrapolate wind speed data to adequate height to our study (110m) [8], [9]:

$$
v_{z}=v_{0}\left(\frac{z}{z_{0}}\right)^{\alpha}
$$

It's assumed to be 0.143 in coastal regions and $0.2-0.3$ in forested area, or evaluated by the following equation:

$$
\alpha=\left[0.37-0.088 \ln \left(c_{0}\right)\right] /\left[1-0.088 \ln \left(\frac{z_{2}}{10}\right)\right]
$$

